\title{
Formation of nanometer-sized Au particles on USY zeolites under hydrogen atmosphere
}

\author{
Kazu Okumura • Chika Murakami • Tetsuya Oyama • \\ Takashi Sanada $\cdot$ Ayano Isoda $\cdot$ Naonobu Katada
}

Published online: 15 May 2012

(C) The Author(s) 2012. This article is published with open access at Springerlink.com

\begin{abstract}
Gold was deposited on ultrastable Y (USY) zeolite using a newly developed method: just mixing an aqueous solution of $\mathrm{HAuCl}_{4}$ and zeolite at $353 \mathrm{~K}$ in which the $\mathrm{NH}_{4}{ }^{+}$cation reacted with the $\mathrm{Cl}^{-}$in $\mathrm{HAuCl}_{4}$. Treatment of the Au-loaded USY zeolite in the atmosphere of hydrogen resulted in the formation of $\mathrm{Au}^{0}$ nanoclusters with $1.8 \mathrm{~nm}$ diameter at $773 \mathrm{~K}$. The size of Au particle was dependent on the type of zeolite support, composition of gas atmosphere, and temperature of calcination, which was correlated with catalytic performance. This study demonstrated the potential use of zeolites with strong Brønsted acid character as gold supports.
\end{abstract}

Keywords Gold cluster · Nanoparticle · USY zeolite · Brønsted acid $\cdot$ Homocoupling

\section{Introduction}

Since the pioneering work by Haruta and co-researchers, efforts have increasingly been directed toward the development of supported Au catalysts [1-4]. Interest in these catalysts is fuelled by their unique catalytic performance in various reactions $[5,6]$. The catalytic performance of $\mathrm{Au}$

\footnotetext{
K. Okumura $(\bowtie) \cdot$ C. Murakami $\cdot$ T. Oyama $\cdot$ T. Sanada $\cdot$

N. Katada

Department of Chemistry and Biotechnology,

Graduate School of Engineering, Tottori University,

4-101 Koyama-cho Minami,

Tottori 680-8552, Japan

e-mail: okmr@chem.tottori-u.ac.jp

T. Sanada $\cdot$ A. Isoda

Research Department, NISSAN ARC, LTD.,

Yokosuka 237-0061, Japan
}

particles is sensitive to the Au particle size, and consequently, the regulation of the size of Au particles is of fundamental importance for the application to catalytic reactions [7]. In particular, high catalytic performance has been reported for Au particles smaller than several nanometers in size [1]. Preceding reports primarily focused on the use of reducible metal oxides such as $\mathrm{TiO}_{2}$ and $\mathrm{Fe}_{2} \mathrm{O}_{3}$ as supports for $\mathrm{Au}$. Other researchers attempted to use zeolites as the supports for $\mathrm{Au}$. For instance, Au loaded on Y-type zeolites has been applied to $\mathrm{CO}$ oxidation [8]. Reduction of $\mathrm{NO}$ by $\mathrm{H}_{2}$ has been performed over $\mathrm{Au}^{0}$ or $\mathrm{Au}(\mathrm{I})$ loaded on $\mathrm{Na}^{+}-\mathrm{Y}$ zeolite [9], and the formation of electron-deficient gold particles inside $\mathrm{H}-\mathrm{Y}$ cavities has been observed [10]. Propene epoxidation by $\mathrm{H}_{2}$ and $\mathrm{O}_{2}$ was carried out over Au/TS-1 [11]. We have also utilized $\mathrm{H}-\mathrm{Y}$ zeolites as a support for $\mathrm{Au}[12,13]$. Zeolites are promising supports for metals because the presence of strongly acidic sites in these materials promotes high dispersion of metal particles. In fact, metal clusters of Pd and Pt with high dispersion were obtained on zeolites having Brønsted acid sites [14, 15]. Ultrastable Y (USY) zeolites contain strongly acid sites [16] (ca. $150 \mathrm{~kJ} \mathrm{~mol}^{-1}$ ) and also exhibit high thermal stability. These acidic sites may be exploited for interaction with $\mathrm{Au}$, and their thermal stability makes USY zeolites attractive for use as Au catalyst supports in high-temperature applications.

To date, several methods including precipitation deposition [17], chemical vapor deposition [18], and cation adsorption [19] have been applied for the preparation of $\mathrm{Au} /$ $\mathrm{TiO}_{2}$ catalysts. Cation exchange using $\left[\mathrm{Au}(\mathrm{en})_{2}\right]^{3+}$ and incipient wetness impregnation have been employed for the loading of zeolites [20, 21].

The purpose of this study is to establish a new method for the preparation of $\mathrm{Au}$ nanoclusters on zeolite supports, demonstrating that nanometer-sized $\mathrm{Au}^{0}$ particles having a narrow size distribution were obtained after calcination at 
temperature higher than $573 \mathrm{~K}$. Moreover, the influences of the concentration of hydrogen in the gas phase and the Brønsted acid strength on the size of Au particles were investigated. Preliminary data were recently reported elsewhere as a communication [22]. In the present study, USY zeolite is used as a support for Au. First, we developed a new method for loading Au on the zeolite support in which $\mathrm{Au}$ was loaded on $\mathrm{NH}_{4}^{+}$-type USY zeolites using an aqueous solution of $\mathrm{HAuCl}_{4}$. Then, the as-prepared Au/USY was thermally treated in an atmosphere of $\mathrm{H}_{2}$ from 353 to $773 \mathrm{~K}$. Changes in the local structure and size of Au were analyzed by X-ray absorption fine structure (XAFS), X-ray diffraction (XRD), and transmission electron microscopy (TEM). Homocoupling of phenylboronic acid was performed as the catalytic reaction. The reason of the choice of this reaction was that the acid sites present in zeolites were supposed not to be influential on the homocoupling reaction.

\section{Experimental}

\section{Sample preparation}

Gold was loaded on an $\mathrm{NH}_{4}$-type USY zeolite (Tosoh, HSZ$341 \mathrm{NHA}, \mathrm{Si} / \mathrm{Al}_{2}=7.7$ ) using $\mathrm{HAuCl}_{4} \cdot 4 \mathrm{H}_{2} \mathrm{O}$ (Wako Chemical Co. $)$ as the precursor. The USY $(1 \mathrm{~g})$ was immersed in an aqueous solution of $\mathrm{HAuCl}_{4}\left(250 \mathrm{~mL}, 6.1 \times 10^{-4} \mathrm{~mol} \mathrm{~L}^{-1}\right)$, and the slurry was kept at $343 \mathrm{~K}$ for $1 \mathrm{~h}$ with constant stirring. The Au-loaded USY zeolite was filtered, washed with deionized water, and dried in an oven at $323 \mathrm{~K}$. The loading of Au was most commonly $3 \mathrm{wt} \%$ as measured by inductively coupled plasma. The obtained Au/USY was typically treated with a stream of $6 \% \mathrm{H}_{2}$ diluted with $\mathrm{Ar}$ at a given temperature for $30 \mathrm{~min}$. Temperature ramping rate for the treatment was $5 \mathrm{~K} \mathrm{~min}^{-1}$. Au/USY samples are henceforth denoted as Au/USY- $x$ in which $x$ represented the calcination temperature. Loading of $\mathrm{Au}$ on $\mathrm{CaNH}_{4}{ }^{+}$-type $\mathrm{Y}$ and $\mathrm{NH}_{4}{ }^{+}$-type $\mathrm{Y}, \mathrm{NH}_{4} \mathrm{NO}_{3}$-treated USY was carried out in a similar way as described for the preparation of Au/USY. Concentration of $\mathrm{Ca}$ in $\mathrm{CaH}-\mathrm{Y}$ was $1.0 \mathrm{~mol} \mathrm{~kg}^{-1}$. Precipitation-deposition method was employed for the loading of $3 \mathrm{wt} \% \mathrm{Au}$ on H-ZSM-5 (JRC-Z5-90H(1),Si/ $/ \mathrm{Al}_{2}=90$ ), Hmordenite (JRC-Z-HM15, Si/Al $2=15$ ), and $\mathrm{TiO}_{2}$ (JRCTIO-11), which were supplied by the Catalysis Society of Japan.

TEM, XAFS, and XRD data collection and analysis

TEM images were acquired using a HITACHI H-9000UHR microscope with an acceleration voltage of $300 \mathrm{kV}$. Synchrotron radiation experiments (XAFS) were performed at the BL01B1 station with the approval of the Japan Synchrotron Radiation Research Institute (Proposal No. 2011A1106,
2011B1095). A Si(111) single crystal was used to obtain a monochromatic X-ray beam. Measurements were recorded in the quick mode at room temperature. For the collection of $\mathrm{Au} \mathrm{L}_{3}$-edge data, ion chambers filled with $\mathrm{N}_{2}$ and a mixture of $\mathrm{N}_{2}(50 \%) / \operatorname{Ar}(50 \%)$ were used for $I_{0}$ and $I$, respectively. The energy was calibrated using an Au foil. The data were analyzed using the REX2000 Ver. 2.5.9 program (Rigaku Co.). Fourier transform of $k^{3} \chi(k)$ data was performed in a $k$ range $30-160 \mathrm{~nm}^{-1}$ for the analysis of the $\mathrm{Au} \mathrm{L}_{3}$-edge extended X-ray absorption fine structure (EXAFS) spectra. The inversely Fourier filtered data were analyzed using a common curve-fitting method. The empirical phase shift and amplitude functions for $\mathrm{Au}-\mathrm{O}$ and $\mathrm{Au}-\mathrm{Au}$ were extracted from the data of FEFF code (ver. 8) and Au foil, respectively. The crystalline structure was analyzed by XRD under ambient conditions using a Rigaku Ultima IV X-ray diffractometer with $\mathrm{Cu} \mathrm{K} \alpha$ radiation.

Catalytic reactions

The samples were pretreated in $6 \% \mathrm{H}_{2}$ at a given temperature before being used in homocoupling reaction of phenylboronic acid. The treated samples were stored in the dark prior to the reaction. Homocoupling reactions were carried out over the Au catalysts. Phenylboronic acid $(0.25 \mathrm{mmol}$; Tokyo Kasei Chemicals Ltd., Japan), $\mathrm{K}_{2} \mathrm{CO}_{3}(0.75 \mathrm{mmol}$; Wako Chemicals Ltd., Osaka, Japan), deionized water (solvent, $5 \mathrm{~mL})$, and Au-loaded catalyst $(16.4 \mathrm{mg}$ ) were used for the reaction. Molar amount of gold was $1 \mathrm{~mol} \%$ with respect to phenylboronic acid. A sample bottle $(20 \mathrm{~mL})$ was placed on a magnetic stirrer and subjected to vigorous stirring. The reaction was performed at $300 \mathrm{~K}$ under atmospheric conditions for $0.5 \mathrm{~h}$. The reaction was quenched by the addition of ethyl acetate. The product was extracted with ethyl acetate. Following evaporation of the ethyl acetate, the residue was analyzed by gas chromatography [Shimadzu 2010 Gas Chromatograph equipped with an InertCap $1(30 \mathrm{~m})$ capillary column (Shimadzu Corp., Kyoto, Japan)]. Tridecane was used as the internal standard.

\section{Results and discussion}

Influence of the calcination temperature on $\mathrm{Au}$ dispersion

In the preparation of $\mathrm{Au} / \mathrm{USY}, \mathrm{Au}$ was loaded on $\mathrm{NH}_{4}-\mathrm{USY}$ using $\mathrm{HAuCl}_{4}$ as the Au precursor. The solution of $\mathrm{HAuCl}_{4}$ had been yellow and it was decolorized, while the zeolites became a pale orange color within $1 \mathrm{~h}$ after temperature of the solution reached $343 \mathrm{~K}$. These changes in color indicate the loading of $\mathrm{Au}$ on USY. Formation of $\mathrm{NH}_{4} \mathrm{Cl}$ in the filtered solution was confirmed by means of IR, XRD, and TG analysis. The molar amount of $\mathrm{NH}_{4} \mathrm{Cl}$ dissolved in the 
a

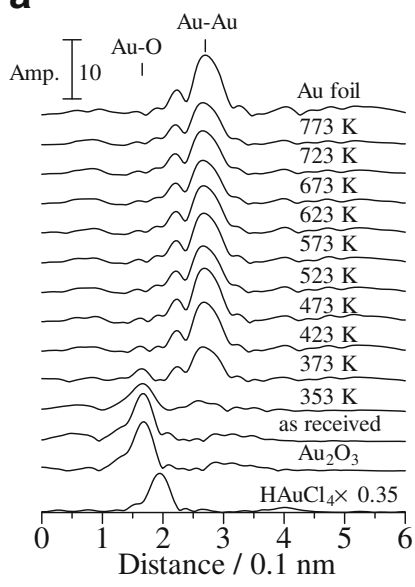

b

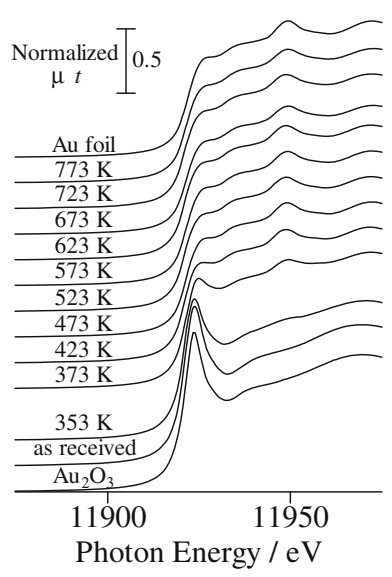

Fig. $1 \mathrm{Au}-\mathrm{L}_{3}$ edge EXAFS $k^{3} \chi(k)$ Fourier transforms (a) and XANES (b) of $3 \mathrm{wt} \% \mathrm{Au} / \mathrm{USY}$ treated at different temperatures under $6 \% \mathrm{H}_{2}$ atmosphere and reference samples. Data collection was carried out at room temperature

solution was four times larger than that of $\mathrm{Au}$, suggesting the following stoichiometry (Eq. 1).

$\mathrm{AuCl}_{4}^{-}+4 \mathrm{NH}_{4}^{+}-$zeolite $\rightarrow \mathrm{Au}^{3+}-$ zeolite $+4 \mathrm{NH}_{4} \mathrm{Cl}$

The $\mathrm{Au}^{3+}$ zeolite was hydrated by water to give $\mathrm{Au}_{2} \mathrm{O}_{3}$ simultaneously according to Eq. 2:

$2 \mathrm{Au}^{3+}-$ zeolite $+3 \mathrm{H}_{2} \mathrm{O} \rightarrow \mathrm{Au}_{2} \mathrm{O}_{3}+6 \mathrm{H}^{+}-$zeolite

The ion exchange sites of USY zeolite should be partially exchanged with $\mathrm{H}^{+}$. Formation of $\mathrm{Au}_{2} \mathrm{O}_{3}$ in the as-prepared sample was confirmed by EXAFS, as mentioned later. Deposition of $\mathrm{Au}$ also proceeded smoothly on $\mathrm{NH}_{4}-\mathrm{Y}$ as confirmed by ICP analysis. In addition, Au was readily supported on $\mathrm{NH}_{4}{ }^{+}$-type USY even at higher loadings of $5 \mathrm{wt} \%$. In marked contrast to the $\mathrm{NH}_{4}{ }^{+}$-type USY, $\mathrm{Au}$ was not deposited on either $\mathrm{H}^{+}$-type USY or $\mathrm{Na}^{+}$-type $\mathrm{Y}$ in a same method; this indicated that the presence of $\mathrm{NH}_{4}{ }^{+}$ cation is indispensable for the loading of Au. Loading of $\mathrm{Au}$ on $\mathrm{NH}_{4}{ }^{+}$-type ZSM5 and mordenite by a same procedure was also attempted. However, deposition of Au was not successful on other kinds of zeolites, except for Y-type materials. Therefore, deposition of Au specifically took place on the $\mathrm{NH}_{4}{ }^{+}$-type $\mathrm{Y}$ and USY zeolites.

Figure 1a shows Au- $\mathrm{L}_{3}$ edge EXAFS of $3 \mathrm{wt} \% \mathrm{Au} / \mathrm{USY}$. The Fourier transform of the as-received sample was identical to those of $\mathrm{Au}_{2} \mathrm{O}_{3}$. The $\mathrm{Au}-\mathrm{O}$ bond appears at $0.17 \mathrm{~nm}$ (phase shift uncorrected). The features of spectrum in the range $0.25-0.40 \mathrm{~nm}$ were also similar to those of $\mathrm{Au}_{2} \mathrm{O}_{3}$. The peak corresponding to the $\mathrm{Au}-\mathrm{Cl}$ was not observed in the Fourier transform. The absence of $\mathrm{Au}-\mathrm{Cl}$ can be confirmed by comparison with $\mathrm{HAuCl}_{4}$ in which the $\mathrm{Au}-\mathrm{Cl}$ bond appears at ca. $0.20 \mathrm{~nm}$ (phase shift uncorrected),

indicating that $\mathrm{Au}$ was successfully loaded on USY as aggregated $\mathrm{Au}_{2} \mathrm{O}_{3}$. The $\mathrm{Au}-\mathrm{O}$ peak was decreased by $\mathrm{H}_{2}$ treatment with temperature elevation, and the peak disappeared at $473 \mathrm{~K}$. Alternatively, a new peak appeared at $0.27 \mathrm{~nm}$, which was assignable to the nearest neighbor $\mathrm{Au}-\mathrm{Au}$ bond in $\mathrm{Au}^{0}$ metal on the basis of comparison with the spectrum of $\mathrm{Au}$ foil. The complete disappearance of the $\mathrm{Au}-\mathrm{O}$ peak at $473 \mathrm{~K}$ indicates the formation of $\mathrm{Au}^{0}$ as a result of $\mathrm{H}_{2}$ reduction at this temperature. Formation of $\mathrm{Au}^{0}$ at $473 \mathrm{~K}$ was also confirmed from the X-ray absorption near edge structure (XANES) regions; the shapes of the XANES profiles were markedly similar to that of Au foil, as shown in Fig. 1b. At temperatures above $473 \mathrm{~K}$, the intensity of EXAFS peak corresponding to the $\mathrm{Au}-\mathrm{Au}$ bond decreased slightly (Fig. 1a). This slight change suggests a decrease in the size of Au particles. The coordination numbers $(\mathrm{CNs})$ of the nearest neighboring $\mathrm{Au}-\mathrm{Au}$ bond in $\mathrm{Au} / \mathrm{USY}$ samples treated at 473 and $773 \mathrm{~K}$ were calculated to be $11.8 \pm 1.6$ and $9.6 \pm 1.4$, respectively. The change in $\mathrm{CNs}$ of $\mathrm{Au}-\mathrm{Au}$ atoms suggested the decrease in the size of the Au particles at higher treatment temperatures. The particle size of the $\mathrm{Au} /$ USY-773 K was estimated to be $2 \mathrm{~nm}$ on the basis of the $\mathrm{CN}=9.6$, assuming a cuboctahedron shape [23].

Because EXAFS analysis is rather insensitive to $\mathrm{CNs}$ when the particle size of a metal is larger than several nanometers, Au/USY was analyzed by XRD, which is sensitive to changes in size of Au particles larger than several nanometers. Figure 2 shows the XRD patterns of the 3 and $5 \mathrm{wt} \% \mathrm{Au} / \mathrm{USY}$ samples treated at various temperatures. The peaks at $2 \theta=38.2^{\circ}$ and $44.4^{\circ}$ were due to the diffractions from the (111) and (200) planes of $\mathrm{Au}^{0}$, respectively. Weak diffractions due to the USY zeolites appeared at $38.1^{\circ}$ and $44.2^{\circ}$, which overlapped with the diffractions from $\mathrm{Au}^{0}$. The intensity of the reflections from the $\mathrm{Au}^{0}(111)$ and (200) planes increased with increasing the treatment temperature from room temperature to $473 \mathrm{~K}$ on the $3 \mathrm{wt} \% \mathrm{H}_{2}$-treated
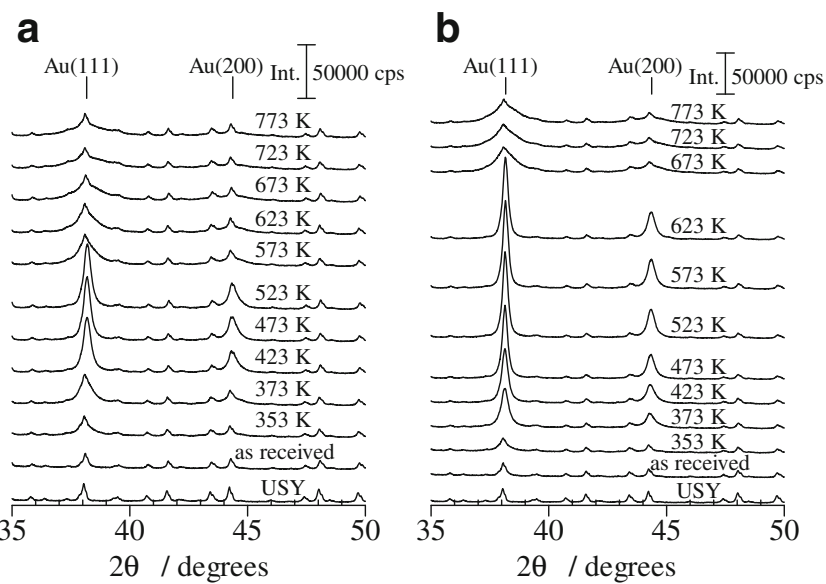

Fig. 2 XRD patterns of Au/USY treated at different temperatures under a $6 \% \mathrm{H}_{2}$ atmosphere: a $3 \mathrm{wt} \%$ and b $5 \mathrm{wt} \%$ 
Fig. 3 TEM images of $\mathrm{Au} /$ USY calcined at a $473 \mathrm{~K}$ and $\mathbf{b}$ $773 \mathrm{~K}$ under an atmosphere of $6 \% \mathrm{H}_{2}$. Loading of $\mathrm{Au}$ was $3 \mathrm{wt} \%$
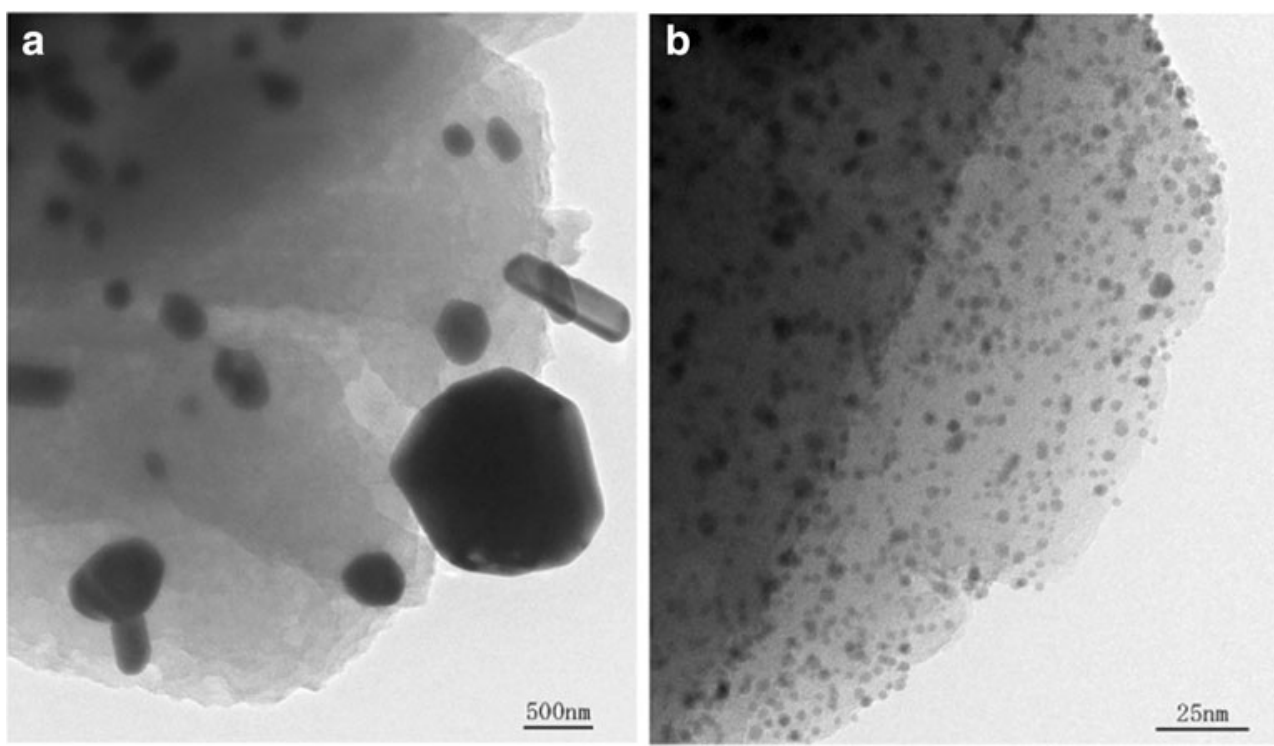

samples (Fig. 2a). This change can be attributed to the formation of $\mathrm{Au}^{0}$ as confirmed by $\mathrm{Au}-\mathrm{L}_{3}$ edge XAFS (EXAFS and XANES). On further increase of the temperature, the intensity of these diffractions decreases, accompanied by peak broadening. A marked reduction of the peaks can be observed at $573 \mathrm{~K}$ indicating that highly dispersed $\mathrm{Au}$ particles were obtained when the treatment temperature was increased from 473 to $773 \mathrm{~K}$. The XRD patterns of $5 \mathrm{wt} \%$ Au-loaded USY (Fig. 2b) exhibit a similar reduction of the $\mathrm{Au}(111)$ and $\mathrm{Au}(200)$ peaks indicative of dispersion of the $\mathrm{Au}^{0}$ particles. However, the reduction in peak intensity was observed in the $5 \mathrm{wt} \%$ sample at $673 \mathrm{~K}$, which was $100 \mathrm{~K}$ higher in the temperature than that for $3 \mathrm{wt} \% \mathrm{Au} /$ USY, suggesting that the extent of Au loading impacts the behavior of Au.

TEM analysis was employed to directly observe the $\mathrm{Au}^{0}$ particles on Au/USY in order to confirm the dispersion of $\mathrm{Au}$. The TEM images of Au/USY treated at 473 and $773 \mathrm{~K}$ under a $6 \% \mathrm{H}_{2}$ atmosphere are shown in Fig. 3a, b, respectively. Large $\mathrm{Au}^{0}$ particles with a variation of size were observed in the image of Au/USY treated at $473 \mathrm{~K}$ (Fig. 3a). The shape of the Au particles was not uniform. In marked contrast to this, and in agreement with the EXAFS and XRD, the particles of $\mathrm{Au}^{0}$ in Au/USY-773 K (Fig. 3b) were much smaller and seem to have a homogeneous size distribution compared to the sample treated at $473 \mathrm{~K}$. Figure 4 shows the particle size distribution of $\mathrm{Au}^{0}$ determined from the TEM images. The $\mathrm{Au}^{0}$ particle sizes ranged from 10 to $150 \mathrm{~nm}$ with an average size of $25 \mathrm{~nm}$ for $\mathrm{Au} / \mathrm{USY}-473 \mathrm{~K}$. The average size of $\mathrm{Au}^{0}$ in $\mathrm{Au} / \mathrm{USY}-773 \mathrm{~K}$ was $1.8 \mathrm{~nm}, 1 / 14$ of that of $\mathrm{Au} / \mathrm{USY}-473 \mathrm{~K}$. The estimated size is consistent with the $\mathrm{Au} \mathrm{L}_{3}$-edge EXAFS analysis. The mean diameter of $\mathrm{Au}(1.8 \mathrm{~nm})$ is slightly larger than the diameter of super cages of in Y-type zeolite $(1.3 \mathrm{~nm})$, suggesting that most of the loaded $\mathrm{Au}$ was located on the external surface of zeolite. The distribution of $\mathrm{Au}^{0}$ particle size in Au/USY-773 K ranges from 0.4 and $5.9 \mathrm{~nm}$, significantly narrower as compared to that in Au/USY-473 K.

The formation of highly dispersed $\mathrm{Au}^{0}$ at $773 \mathrm{~K}$ thus demonstrated by TEM coupled with EXAFS and XRD is unusual, because supported metal particles generally undergo sintering to form aggregates at high temperature in reductive atmosphere. It has been known that oxidative atmosphere can keep small particles of metal oxides; dispersion of $\mathrm{Pd}$ and $\mathrm{Pt}$ as cations has been observed under an atmosphere of oxygen [24]. We have also reported the spontaneous dispersion of molecular-like PdO on H-ZSM5 [25]. In contrast to the above-mentioned examples, the dispersed $\mathrm{Au}^{0}$ was obtained on USY zeolite support under an atmosphere of $\mathrm{H}_{2}$ at high temperature in the present study. The origin of dispersion of $\mathrm{Au}^{0}$ on USY zeolites has not been fully elucidated on this stage; however, one hypothesis is that the interaction of $\mathrm{Au}$ and $\mathrm{H}^{+}$generated as a result of thermal decomposition of $\mathrm{NH}_{4}{ }^{+}$causes the dispersion of Au on the external surface of USY zeolites. As a matter of fact, Sachtler et al. proposed the possibility of the generation of $\left[\mathrm{Pd}_{n} \mathrm{H}\right]^{+}$adducts encaged in zeolite pores [26, a

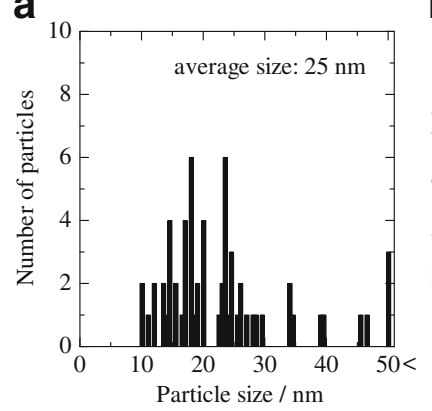

b

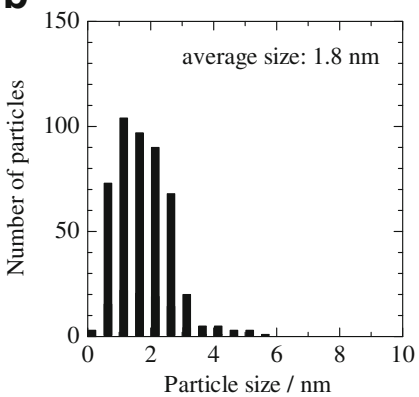

Fig. 4 Distribution of Au/USY calcined at a $473 \mathrm{~K}$ and b $773 \mathrm{~K}$ under an atmosphere of $6 \% \mathrm{H}_{2}$. Loading of Au was $3 \mathrm{wt} \%$ 

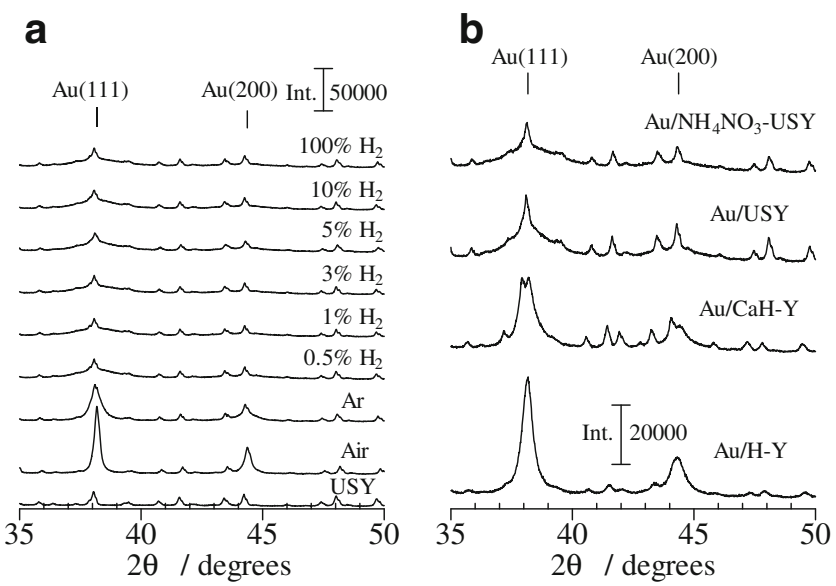

Fig. $5 \mathrm{XRD}$ patterns of a Au/USY treated at $773 \mathrm{~K}$ in different atmosphere for $0.5 \mathrm{~h}$, b Au loaded on Y-type zeolites calcined at $773 \mathrm{~K}$ in $6 \% \mathrm{H}_{2}$

27]. Similarly, Fraissard et al. reported the chemical anchoring of Au clusters by the Brønsted sites of the support in $\mathrm{Au} /$ Y-type zeolites [20].

Influence of the concentration of $\mathrm{H}_{2}$ and time on the dispersion of $\mathrm{Au}$

Figure 5a shows XRD patterns of $3 \mathrm{wt} \% \mathrm{Au} / \mathrm{USY}$ treated under different atmospheres at $773 \mathrm{~K}$. Steep diffraction peaks appeared in the samples calcined in air or Ar, namely $0 \% \mathrm{H}_{2}$. Addition of $0.5 \% \mathrm{H}_{2}$ to the atmosphere resulted in the formation of dispersed Au as confirmed from the broadening of diffraction peaks due to metal Au. No further change was observed with increasing the hydrogen concentration up to $100 \%$, leading us to conclude that the presence of low levels of hydrogen is sufficient to give rise to the dispersion to give nanometer-sized Au clusters. Figure 6 shows TEM images and particle size distribution of $3 \mathrm{wt} \%$ $\mathrm{Au} / \mathrm{USY}$ treated under an atmosphere containing $\mathrm{Ar}$ and $0.5 \% \mathrm{H}_{2}$, corresponding to the samples in Fig. 5a, respectively. The sizes of Au particles in the sample treated in the atmosphere of Ar are distributed over 4 to $59 \mathrm{~nm}$ with an average diameter of $14.6 \mathrm{~nm}$. In marked contrast to $\mathrm{Au} / \mathrm{USY}$ treated in $\mathrm{Ar}$, the distribution $(1-8 \mathrm{~nm})$ of the size of $\mathrm{Au}$ treated under an atmosphere of $0.5 \% \mathrm{H}_{2}$ is narrower and the average size $(3.7 \mathrm{~nm})$ is appreciably smaller. The treatment times of Au/USY were varied from $10 \mathrm{~min}$ to $10 \mathrm{~h}$ under an atmosphere comprising $6 \% \mathrm{H}_{2}$ at $773 \mathrm{~K}$. No differences were observed in the diffraction patterns obtained for these samples, implying that dispersion of Au occurs immediately when the temperature reaches $773 \mathrm{~K}$. Although the role of hydrogen is not clearly understood at this stage, the TEM images of Au/USY treated in different atmospheres indicate that the presence of hydrogen has a profound influence on the dispersion of $\mathrm{Au}$.
Influence of the acid strength of supports on the dispersion of $\mathrm{Au}$

The acid strength of Brønsted acid sites present in Ytype zeolites can be finely tuned by (a) the introduction of divalent cations such as $\mathrm{Ca}^{2+}$ and (b) by dealumination in combination with posttreatment employing an aqueous solution of ammonium salts [16]. The influence of the acid strength on the dispersion of Au was examined by employing four types of Y-type zeolite supports: $\mathrm{H}-\mathrm{Y}, \mathrm{CaH}-\mathrm{Y}$, USY, and $\mathrm{NH}_{4} \mathrm{NO}_{3}$-treated USY. The highest acid strengths (heat of ammonia desorption) of the Brønsted acid sites present in $\mathrm{H}-\mathrm{Y}, \mathrm{CaH}-\mathrm{Y}$, USY, and $\mathrm{NH}_{4} \mathrm{NO}_{3}$-treated USY are 109, 122, 140, and $157 \mathrm{~kJ} \mathrm{~mol}^{-1}$, respectively. The acid strength increased in the following order: $\mathrm{H}-\mathrm{Y}<\mathrm{CaH}-\mathrm{Y}<\mathrm{USY}<\mathrm{NH}_{4} \mathrm{NO}_{3}$ treated USY. In the preparation of $\mathrm{CaH}-\mathrm{Y}$ support, $30 \%$ of $\mathrm{NH}_{4}^{+}$present in $\mathrm{NH}_{4}^{+}$-type $\mathrm{Y}$ was exchanged with $\mathrm{Ca}^{2+}$ using $\mathrm{Ca}\left(\mathrm{NO}_{3}\right)_{2}$. Figure $5 \mathrm{~b}$ shows XRD patterns of $3 \mathrm{wt} \% \mathrm{Au}$ loaded on these supports. The samples were calcined at $773 \mathrm{~K}$ under a $6 \% \mathrm{H}_{2}$ atmosphere. It can be seen that the intensity of the diffractions assignable to the $\mathrm{Au}(111)$ and (200) decrease with an increase in the intensity of acid strength of Y-type supports, suggesting that the greater the acid strength, the smaller the Au particles become.

Figure 7 displays TEM images of Au loaded on different Y-type zeolites, corresponding to the XRD patterns of
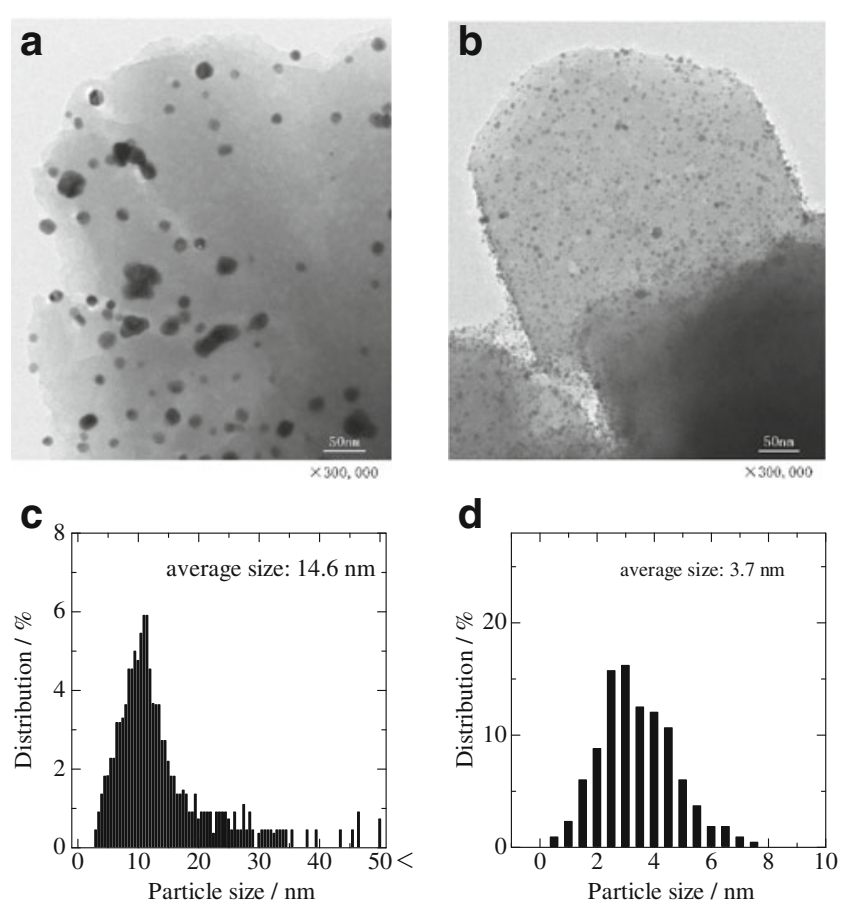

Fig. 6 TEM images of Au/USY calcined in a $\mathrm{Ar}$ and $\mathbf{b} 0.5 \% \mathrm{H}_{2}$ at $773 \mathrm{~K}$. Distribution of $\mathrm{Au}$ particles in $3 \mathrm{wt} \% \mathrm{Au}$ loaded on USY calcined in (c) $\mathrm{Ar}$ and (d) $0.5 \% \mathrm{H}_{2}$ 
Fig. 7 TEM images of $3 \mathrm{wt} \%$ Au loaded on a $\mathrm{H}-\mathrm{Y}$, b CaH-Y, c USY, and $\mathbf{d} \mathrm{NH}_{4} \mathrm{NO}_{3}-\mathrm{USY}$

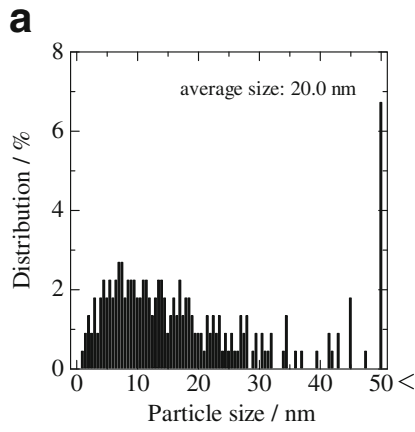

b

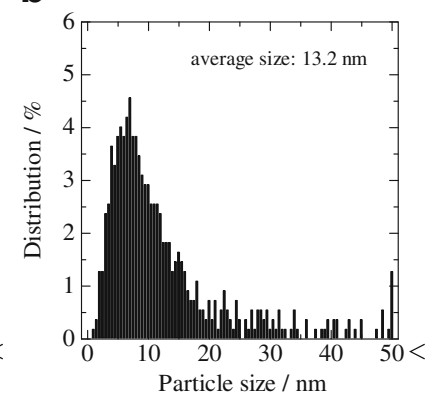

d

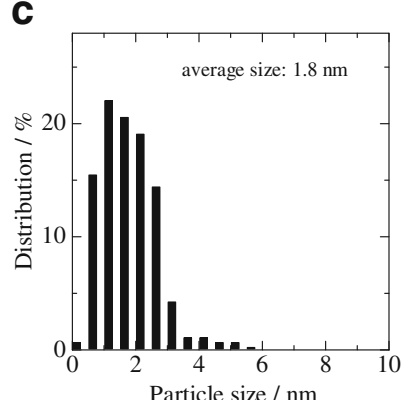

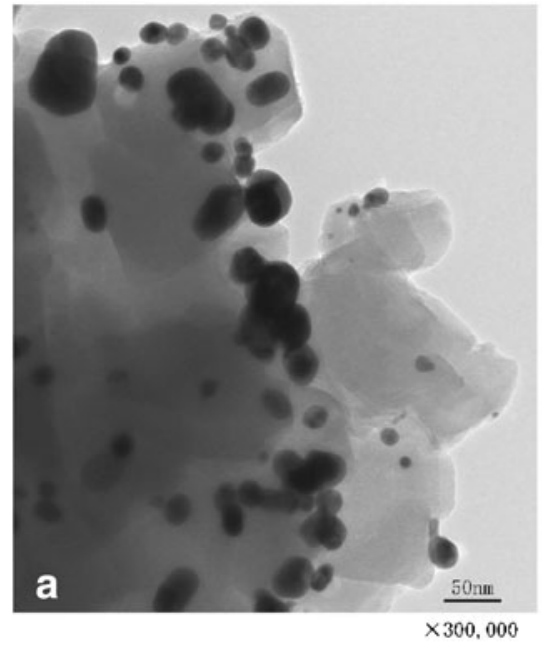
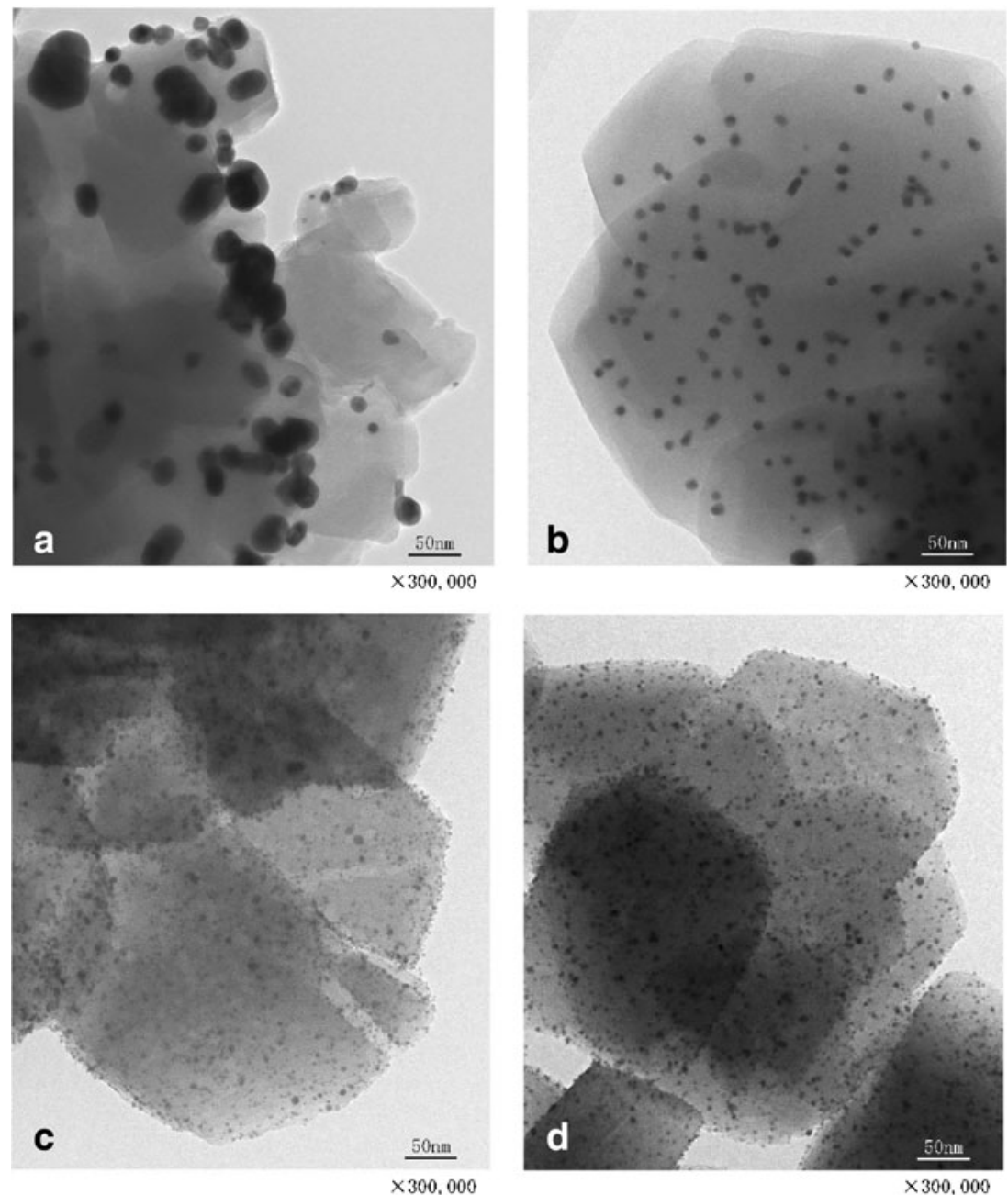

Fig. 5b. The distribution of the size of Au particles in these samples is summarized in Fig. 8. An inhomogeneous distribution of large $\mathrm{Au}$ particles can be seen in the image of $\mathrm{Au} / \mathrm{H}-\mathrm{Y}$ (Fig. 7a). The size distribution plot confirms this observation (Fig. 8a). In the case of $\mathrm{Au} /$ $\mathrm{CaH}-\mathrm{Y}$, uniform $\mathrm{Au}$ particles ca. $10 \mathrm{~nm}$ in diameter can

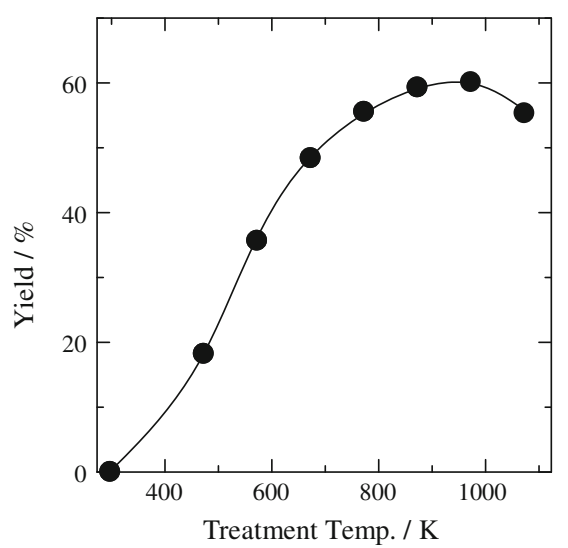

Fig. 8 Distribution of Au particles in $3 \mathrm{wt} \%$ Au loaded on a H-Y, b $\mathrm{CaH}-\mathrm{Y}$, c USY, and $\mathbf{d} \mathrm{NH}_{4} \mathrm{NO}_{3}-\mathrm{USY}$

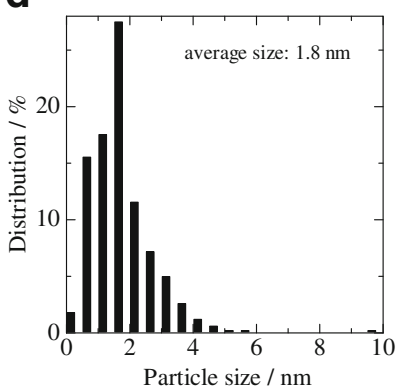

Fig. 9 Dependence of the yield of product (biphenyl) on the calcination temperature of $3 \mathrm{wt} \% \mathrm{Au} / \mathrm{USY}$ treated in a stream of $6 \% \mathrm{H}_{2}$ 
be seen (Fig. 7b). Although the size distribution of $\mathrm{Au}$ particles in $\mathrm{Au} / \mathrm{CaH}-\mathrm{Y}$ is much narrower compared to that of $\mathrm{Au} / \mathrm{H}-\mathrm{Y}$, some large particles can also be observed in the TEM images. The average particle size of $\mathrm{Au}$ loaded on USY and $\mathrm{NH}_{4} \mathrm{NO}_{3}$-treated USY is $1.8 \mathrm{~nm}$, a significantly smaller value than those of $\mathrm{Au}$ particles loaded on $\mathrm{H}-\mathrm{Y}$ and $\mathrm{CaH}-\mathrm{Y}$. Despite the identical average size of $\mathrm{Au}$ in the USY and $\mathrm{NH}_{4} \mathrm{NO}_{3}-\mathrm{USY}(1.8 \mathrm{~nm})$, the $\mathrm{Au} / \mathrm{NH}_{4} \mathrm{NO}_{3}-\mathrm{USY}$ shows a narrower distribution compared to Au/USY. The TEM images in combination with XRD patterns prove that the size of the Au particles is dependent on the acid strength of Y-type zeolites, indicating that the presence of the strong Brønsted acid sites induces the formation of nanometer-sized $\mathrm{Au}$ particles with a narrow size distribution.

Catalytic performance in the homocoupling reaction

The homocoupling reaction of phenylboronic acid was carried out over the Au-loaded catalysts. Figure 9 shows the yield of biphenyl product plotted as a function of calcination temperature of $3 \mathrm{wt} \% \mathrm{Au} / \mathrm{USY}$. The yield of biphenyl increased as the calcination temperature increased. The highest yield $(60 \%)$ was obtained when the catalyst was calcined at $773-1,073 \mathrm{~K}$. The catalytic activity of the Au/USY was equal to the performance of $\mathrm{Au}$ nanoclusters protected by PVP polymers [28]. The change in the particle size of Au can be seen to influence the catalytic activity; the yield of biphenyl increases as the particle size of $\mathrm{Au}$ particles decreases. Formation of biphenyl was negligible over USY zeolites without the loading of $\mathrm{Au}$.

Catalytic reaction was carried out over 1.8-nm-sized Au-loaded USY in which the acid sites were changed to $\mathrm{NH}_{4}{ }^{+}$through the exposure of $\mathrm{NH}_{3}$. The yield of biphenyl over the $\mathrm{Au}$ loaded on $\mathrm{NH}_{4}{ }^{+}$-type USY (60\%) was close to that obtained in $\mathrm{Au}$ loaded on $\mathrm{H}^{+}$-type USY, meaning the acid sites were not influential on the catalytic performance of Au.

$\mathrm{Au}$ was loaded on different types of support using the deposition precipitation method. The yields of biphenyl obtained with $\mathrm{Au} / \mathrm{TiO}_{2}, \mathrm{ZSM}-5$, mordenite, and $\mathrm{Na}-\mathrm{Y}$ were $35,35,36$, and $4 \%$, respectively. The yields obtained with $\mathrm{Au} / \mathrm{H}-\mathrm{Y}$ and $\mathrm{CaH}-\mathrm{Y}$ were and 16 and $17 \%$, respectively, lower than that obtained with $\mathrm{Au} /$ USY-773-1,073 K; this indicated that Au loaded on the USY zeolite afforded the highest activity. Calcination atmosphere affected the catalytic activity significantly as expected from the difference in the dispersion. The yields of biphenyl obtained with Au/USY calcined in Ar and air were 18 and $6 \%$ respectively, which was much lower than that obtained after calcination in the atmosphere of $\mathrm{H}_{2}(60 \%)$.

\section{Conclusions}

Reduction of $\mathrm{Au}_{2} \mathrm{O}_{3}$ on USY zeolites exhibiting strong Brønsted acid character, in the presence of hydrogen, afforded nanometer-sized Au clusters with mean diameter of $1.8 \mathrm{~nm}$. Various factors including temperature ( $>573 \mathrm{~K}$ ), composition of gas phase (hydrogen), and acid strength (USY zeolites exhibiting strong Brønsted acid) of the support were shown to greatly influence the dispersion of Au. For instance, the average size of $\mathrm{Au}$ particles in Au/USY $(1.8 \mathrm{~nm})$ was 11 times smaller than that of $\mathrm{Au} / \mathrm{H}-\mathrm{Y}(20 \mathrm{~nm})$. The catalytic activity of $\mathrm{Au} /$ USY in the homocoupling reaction of phenylboronic acid was in good correlation with the dispersion of $\mathrm{Au}$. That is to say, the yield of biphenyl increased from $16 \%(\mathrm{Au} /$ $\mathrm{H}-\mathrm{Y})$ to $60 \%(\mathrm{Au} / \mathrm{USY})$ by employing the USY supports having strong acid character ca. $150 \mathrm{~kJ} \mathrm{~mol}^{-1}$. The simplicity of technique used for loading of $\mathrm{Au}$ should be emphasized; stirring a solution of $\mathrm{HAuCl}_{4}$ and $\mathrm{NH}_{4}{ }^{+}$type USY zeolite at $343 \mathrm{~K}$ afforded $\mathrm{Au}_{2} \mathrm{O}_{3}$. This study shows the possibility of regulating the size of metal particles by making use of the strong interactions between $\mathrm{Au}$ and zeolite supports.

Open Access This article is distributed under the terms of the Creative Commons Attribution License which permits any use, distribution and reproduction in any medium, provided the original author(s) and source are credited.

\section{References}

1. Haruta M (1997) Catal Today $36: 153$

2. Daniel MC, Astruc D (2004) Chem Rev 104:293

3. Haruta M (2004) Gold Bulletin 37:27

4. Bond GC, Thompson DT (1999) Catal Rev 41:319

5. Haruta M, Date M (2001) Appl Catal A 222:427

6. Corma A, Garcia H (2096) Chem Soc Rev 2008:37

7. Subramanian V, Wolf EE, Kamat PV (2004) J Am Chem Soc 126:4943

8. Fierro-Gonzalez JC, Gates BC (2004) J Phys Chem B 108:16999

9. Salama TM, Ohnishi R, Shido T, Ichikawa M (1996) J Catal $162: 169$

10. Guillemot D, Borovkov VY, Kazansky VB, PolissetThfoin M, Fraissard J (1997) J Chem Soc Faraday Trans 93:3587

11. Huang JH, Lima E, Akita T, Guzman A, Qi CX, Takei T, Haruta M (2011) J Catal 278:8

12. Okumura K, Yoshino K, Kato K, Niwa M (2005) J Phys Chem B 109:12380

13. Shimizu K, Yamamoto T, Tai Y, Okumura K, Satsuma A (2011) Appl Catal A 400:171

14. Okumura K, Yoshimoto R, Uruga T, Tanida H, Kato K, Yokota S, Niwa M (2004) J Phys Chem B 108:6250

15. Treesukol P, Srisuk K, Limtrakul J, Truong TN (2005) J Phys Chem B 109:11940 
16. Okumura K, Tomiyama T, Morishita N, Sanada T, Kamiguchi K, Katada N, Niwa M (2011) Appl Catal A 405:8

17. Hayashi T, Tanaka K, Haruta M (1998) J Catal 178:566

18. Okumura M, Nakamura S, Tsubota S, Nakamura T, Azuma M, Haruta M (1998) Catal Lett 51:53

19. Zanella R, Giorgio S, Henry CR, Louis C (2002) J Phys Chem B 106:7634

20. Riahi G, Guillemot D, Polisset-Thfoin M, Khodadadi AA, Fraissard J (2002) Catal Today $72: 115$

21. Delannoy L, El Hassan N, Musi A, Le To NN, Krafft JM, Louis C (2006) J Phys Chem B 110:22471
22. Sanada T, Okumura K, Murakami C, Oyama T, Isoda A, Katada N (2012) Chem Lett 41:337

23. Jentys A (1999) PhysChemChemPhys 1:4059

24. Bera P, Patil KC, Jayaram V, Subbanna GN, Hegde MS (2000) J Catal 196:293

25. Okumura K, Amano J, Yasunobu N, Niwa M (2000) J Phys Chem B 104:1050

26. Homeyer ST, Karpinski Z, Sachtler WMH (1990) J Catal 123:60

27. Bai XL, Sachtler WMH (1991) J Catal 129:121

28. Tsunoyama H, Sakurai H, Ichikuni N, Negishi Y, Tsukuda T (2004) Langmuir 20:11293 